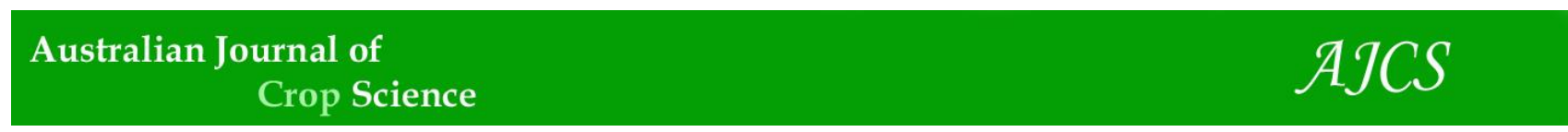

AJCS 10(9):1348-1356 (2016)

ISSN:1835-2707

DOI: 10.21475/ajcs.2016.10.09.p7864

\title{
Stable reference genes for studies of gene expression in Prunus persica under water stress
}

\author{
Leticia Neutzling Rickes", Elsa Kuhn Klumb, Letícia Carvalho Benitez, Eugenia Jacira Bolacel Braga, \\ Valmor João Bianchi
}

Institute of Biology, Departament of Botany, University Federal of Pelotas, Campus Universitário, s/n C.P. 345, Capão do Leão, RS, Brazil

*Corresponding author: leticiarickes@hotmail.com

\begin{abstract}
Strategies which allow the unequivocal identification of genes expressed in response to different treatments and/or stress conditions are important to obtain reliable results in plant physiology studies. However, in order to analyze the expression levels of target genes through RT-qPCR technique, it is essential to use model genes with uniform expression levels under specific experimental conditions. The present study aimed at investigating the stability of reference genes in peach leaves cultivar scion Chimarrita grafted onto 'Aldrighi 1' and 'Tsukuba 2' rootstock, subjected to water deficit for a 9-day period. The experiment was conducted in a completely randomized design with four treatments that correspond the evaluations period: zero (control), $4^{\text {th }}, 7^{\text {th }}$, and $9^{\text {th }}$ stress day of water deficit. For each treatment three biological replicates was used. Eight reference genes were analyzed, among them: $A C T$, $C Y P 2, E f-1 \alpha, G A P D H, T U A, T U B, U B Q 10$ and $18 S r R N A$. For the normalization and validation of RT-qPCR data were used the four major software programs currently available: geNorm, NormFinder, BestKeeper, and Comparative $\Delta \mathrm{C}_{\mathrm{T}}$. The results showed that there was no influence of different plant grafting combinations in the expression of all reference genes evaluated, yet genes TUA and $C Y P 2$ had the most stable expression in the leaves of the peach plants under water deficit for 9-d, whereas genes $E f-1 \alpha$ and $A C T$ were the least stable ones for the same stress conditions.
\end{abstract}

Keywords: cyclophilin 2; rootstock; RT-qPCR; water stress, $\alpha$-Tubulin.

Abbreviations: $A C T \_$actin; $\alpha T U A \_$alfa-tubulin; $C V_{-}$coefficient of variation; $\mathrm{C}_{\mathrm{T}}$ Cycle Threshold; CYP2_Cyclophilin 2; Ef1 $\alpha$ Elongation factor 1- $\alpha$; GAPDH_Glyceraldehyde-3-phosphate dehydrogenase; RT-qPCR_Reverse transcription quantitative PCR; SD_standard deviation; UBQ10_Ubiquitin10; 18SrRNA_18S ribosomal RNA.

\section{Introduction}

Peach (Prunus persica L. Batsch) is one of the most important fruit species of temperate climate worldwide (Luo et al., 2014). However, among abiotic factors, water stress is a common phenomenon that seriously affects the yield of this crop at some phenological stages, such as flowering which can lead to the abortion of flowers and fruits, in the intense cell division period of fruits, as well as at the stage preceding fruit ripening (Dichio et al., 2006; Timm et al., 2007; Mercier et al., 2009; Wang and Gartung, 2010). Water deficit inhibits the growth and development of plants, directly affecting the photosynthetic process lead to the reduction of stomatal conductance, transpiration, osmotic potential and leaf area, speeding up the senescence and leaf abscission (Chaves et al., 2009), resulting in physiological limitations that may cause severe decreases in plant yield (Nakashima et al., 2014).

Plants have evolved under different environmental conditions and, thus, developed extremely complex molecular and genetic processes important for their survival in such conditions (Le et al., 2012). Many of the primary processes that plants use in face of adverse conditions are not constitutively active all the time, but rather induced when they are present, triggering signal transduction cascades which, therefore, activate/suppress several genes related to stress response, leading to biochemical and physiological changes (Nakashima et al., 2014). There are several studies on Prunus using strategies that allow the identification of genes expressed in response to different treatments and/or stress conditions (Almada et al., 2013; Jiménez et al., 2013; Niu et al., 2014; Arismendi et al., 2015), however, it is necessary that in such trials a few genes are selected as candidate genes, which must be validated in more specific analyses in order to quantify their expression in response to stress. One technique widely used for the determination of gene expression is RT-qPCR (quantitative RT-PCR) based on the procedure of reverse transcription (RT) followed by DNA-Polymerase Chain Reaction (PCR). The outcomes are monitored at each reaction cycle, enabling faster and more accurate detection of amplified cDNA with high sensitivity and specificity in the analysis of transcripts (Gachon et al., 2004). The reliability of RT-qPCR technique depends on specific experimental strategies which seek to minimize variations in quality, stability, and integrity of RNA, as well as on the efficiency of cDNA synthesis (Derveaux et al., 2010). Among such strategies, the selection of reference genes suitable to normalize the data is essential to provide accurate results and reliable interpretation. A suitable reference gene must be expressed at a constant level among samples and its expression cannot be affected by different experimental conditions (Bustin, 2002). The use of unsuitable reference genes may result in quantifications errors and, subsequently, expression data may be misinterpreted (Jain et al., 2006; Amil-Ruiz et al., 2013). 
The reference genes used are generally those involved in basic cellular processes, such as primary metabolism and maintenance of cell structure (Expósito-Rodríguez et al., 2008). Those most commonly tested in RT-qPCR studies in plants include Actin (ACT), glyceraldehyde-3-phosphate dehydrogenase $(G A D P H)$, Elongation factor-1 $\alpha(E f-1 \alpha)$, Tubulin ( $\alpha$-TUA and $\beta$-TUA), ubiquitin (UBQ5, UBQ10), ribosomal RNA (18SrRNA, 40S), and cyclophilin (CYP) (Jain et al., 2006; Tong et al., 2009; Le et al., 2012; Huang et al., 2014; Hu et al., 2014; Niu et al., 2014; Moraes et al., 2015; Ye et al., 2015; Galli et al., 2015). Nevertheless, studies have shown that the expression of many of these reference genes may have different expression between genotypes, tissues, organs, and developmental stages (Tong et al., 2009; Le et al., 2012; Hu et al., 2014; Niu et al., 2014; Galli et al., 2015; Moraes et al., 2015; Ye et al., 2015). Thus, the selection of suitable reference genes for the normalization of each crop and experimental condition is crucial.

In the past decades, several mathematical methods and software programs were developed to analyze the variability of reference gene expression, such as NormFinder, which evaluates the total variation in gene expression through the sum of the variance (Andersen et al., 2004). BestKeeper, in turn, uses values of standard deviation and coefficient of variation to calculate the intrinsic variance of expression (Pfaffl et al., 2004). The algorithm geNorm selects the two most stable genes or the multiple combination of several stable genes by calculating the mean stability of expression (M) through the arithmetic mean of each normalizing gene compared pairwise (Vandesompele et al., 2002). The $\Delta C_{T}$ method calculates the relative expression of pairs of genes within each treatment by measuring the gene stability through mean standard deviation values comparing a normalizing gene and other candidate genes (Silver et al., 2006).

Considering the Prunus plants can be affected by various abiotic stress, in different seasons of the year around the world, the identification of more stable expressed genes in each condition of stress is important to obtain unequivocal gene expression data interpretation. Thereby, the present study aimed at investigating the expression of eight reference genes through RT-qPCR technique in order to identify proper normalizing genes for studies in peach trees under water deficit.

\section{Results}

\section{Specificity and efficiency of standard curve of reference genes}

Primers amplified specific products which was confirmed by the presence of a single peak of dissociation curves (melting curve), demonstrating the specificity of the PCR product (Fig 1. and Fig 2). By analyzing the curve at the end of the reaction, it is possible to evaluate the fluorescence of the samples in relation to the increasing temperature because each amplicon has a specific fusion temperature, which enables the differentiation of products resulting from PCR (Pfaffl, 2001).

The efficiency of primers amplification in each one graft combinations 'Chimarrita'/rootstock peach plant was based on values obtained from the Logarithm (log) of cDNA dilutions $(1: 1,1: 5,1: 25$ and 1:125). The efficiency of amplification varied between 1.89 and 2.20 , indicating that at the end of each cycle, the target transcript was duplicated (Fig 1. and Fig 2). However, there was an exception for the reference gene 18SrRNA tested in the graft combination 'Chimarrita/Aldrighi 1', which showed an efficiency over the threshold usually acceptable $(E=2.39)$. The same has not been found for the combination 'Chimarrita/Tsukuba 2' with values of $E=1.92$.

For the most gene tested, the coefficient of determination $\left(\mathrm{R}^{2}\right)$ were above the minimum value acceptable of 0.7 or $70 \%$, except for the genes $E f-1 \alpha$ and $18 S r R N A$ in the combination 'Chimarrita/Aldrighi 1', which had $\mathrm{R}^{2}$ bellow the acceptable $\left(R^{2}=0.673\right.$ and 0.594 , respectively) (Fig 1.), as proposed by Pfaffl (2001).

\section{Standard deviation and coefficient of variation of reference genes}

With respect to the standard deviation (SD) and coefficient of variation (CV\%), TUA and CYP2 were those genes with the lowest SD (0.40 and 0.36, respectively) and CV\% (11.01 and 11.22 , respectively) values for the graft combination 'Chimarrita/Aldrighi 1' (Table 2). The same trend has been found for 'Chimarrita/Tsukuba 2' where TUA had the lowest SD (0.20) and CV\% (8.42) values, indicating higher stability of expression of this gene for both combinations. On the other hand, the ACT gene had the highest SD values, between 2.36 ('Chimarrita/Aldrighi 1') and 1.25 ('Chimarrita/Tsukuba 2') and CV\% values between 45.71 ('Chimarrita/Aldrighi 1') and 63.44 ('Chimarrita/Tsukuba 2') in comparison to the other genes tested.

\section{Analysis by RefFinder of reference genes}

The results obtained with RefFinder were similar in the subset of both graft combinations of 'Chimarrita'/rootstocks of peach trees in the present study. The most unstable gene was $A C T$ followed by $E f-1 \alpha$ (Fig 3 A-E and Fig 4 A-E), suggesting that these classic reference genes are unsuitable to normalize RT-qPCR data under the experimental conditions investigated in the present study.

According to $\Delta \mathrm{C}_{\mathrm{T}}$ comparative method, the most stable reference gene under the experimental condition tested (water deficit) was the gene TUA with the lowest $\mathrm{M}$ values for 'Chimarrita/Aldrighi 1' (1.19) and 'Chimarrita/Tsukuba 2' (0.79), followed by the second most stable gene, CYP2 (Fig 3A and Fig 4A). The M value is defined by Chen et al. (2011) as the mean variation of a given gene in relation to all the other tested genes.

The standard stability of expression found with the BestKeeper algorithm differed from the other algorithms, evidencing that $18 S r R N A$ genes in the graft combination 'Chimarrita/Aldrighi 1' and $U B Q 10$ in the combination 'Chimarrita/Tsukuba 2' were the most stable genes, meanwhile $A C T$ followed by $E F-1 \alpha$ were the least stable ones for both 'Chimarrita/rootstock' combinations (Fig 3B and Fig 4B).

According to the algorithm of the program NormFinder, the reference gene with the lowest $\mathrm{M}$ value was $G A P D H(\mathrm{M}=$ 0.58 - 'Chimarrita/Aldrighi 1'), followed by TUA $(\mathrm{M}=0.65)$ (Fig 3C). For the graft combination 'Chimarrita/Tsukuba 2', in turn, the gene TUA was the most stable with the lowest $\mathrm{M}$ value $(0.46)$ followed by $T U B(\mathrm{M}=0.53)$ and $U B Q 10(\mathrm{M}=$ 0.555). In this graft combination, the gene $G A P D H$ was highly unstable, ranking in the seventh position $(\mathrm{M}=0.74)$ (Fig 4C). The same has been found with the algorithms of $\Delta \mathrm{C}_{\mathrm{T}}$ comparative method $(\mathrm{M}=0.97)(\mathrm{Fig} 4 \mathrm{~A})$ and geNorm $(\mathrm{M}=0.81)$ (Fig 4D).

Based on $\mathrm{M}$ values calculated for eight genes tested, it was found that TUA/CYP2 (M = 0.43; $\mathrm{M}=0.35)$ (Fig 3D and Fig $4 \mathrm{D}$, respectively) were the most stable for both graft combinations cultivar-scion/rootstocks in the present study, 
Table 1. Description of eight reference genes tested in RT-qPCR reactions in peach trees under water deficit.

\begin{tabular}{|c|c|c|c|c|c|}
\hline $\begin{array}{l}\text { Gene } \\
\text { symbol }\end{array}$ & $\begin{array}{l}\text { Local and number } \\
\text { access }\end{array}$ & $\begin{array}{l}\mathrm{T}^{\circ} \text { Melting } \\
\left({ }^{\circ} \mathrm{C}\right)\end{array}$ & $\begin{array}{l}\text { Forward primer sequence } \\
\left(5^{\prime}-3^{\prime}\right)\end{array}$ & Reverse primer sequence ( $\left.5^{\prime}-3^{\prime}\right)$ & Reference \\
\hline$A C T$ & Peach EST TC1223 & 57.5 & $\begin{array}{l}\text { GTTATTCTTCATCGGCGT } \\
\text { CTTCG }\end{array}$ & $\begin{array}{l}\text { CTTCACCATTCCAGTTCCA } \\
\text { TTGTC }\end{array}$ & Tong et al. (2009) \\
\hline$E f-1 \alpha$ & GeneBank DW355834 & 56.2 & $\begin{array}{l}\text { AATTGCCTTTGTTCCCAT } \\
\text { CTCTG }\end{array}$ & $\begin{array}{l}\text { TGGGCTCCTTCTAATCTCC } \\
\text { TTA }\end{array}$ & Xu et al. (2008) \\
\hline$C Y P 2$ & Peach EST TC1916 & 56.3 & $\begin{array}{l}\text { ACTCCAAAGCGTGTTAG } \\
\text { AAAAGG }\end{array}$ & $\begin{array}{l}\text { GTCTCTTCCACCATAACGA } \\
\text { TAGG }\end{array}$ & Tong et al. (2009) \\
\hline$G A D P H$ & Peach EST TC3113 & 57.0 & $\begin{array}{l}\text { ATTTGGAATCGTTGAGG } \\
\text { GTCTTATG }\end{array}$ & $\begin{array}{l}\text { AATGATGTTGAAGGAAGC } \\
\text { AGCAC }\end{array}$ & Tong et al. (2009) \\
\hline$T U A$ & Peach EST TC2873 & 56.9 & $\begin{array}{l}\text { TTCTCTCTACTCATTCCC } \\
\text { TCСТTG }\end{array}$ & $\begin{array}{l}\text { GATTGGTGTATGTTGGTCT } \\
\text { CTCG }\end{array}$ & Tong et al. (2009) \\
\hline$T U B$ & Peach EST TC3624 & 59.5 & $\begin{array}{l}\text { CCGAGAATTGTGACTGC } \\
\text { CTT CAAG }\end{array}$ & $\begin{array}{l}\text { AGCATCATCCTGTCTGGGT } \\
\text { ATTCC }\end{array}$ & Tong et al. (2009) \\
\hline$U B Q 10$ & Peach EST TC2782 & 57.0 & $\begin{array}{l}\text { AAGGCTAAGATCCAAGA } \\
\text { CAAAGAG }\end{array}$ & $\begin{array}{l}\text { CCACGAAGACGAAGCACT } \\
\text { AAG }\end{array}$ & Tong et al. (2009) \\
\hline 18SrRNA & Peach EST TC1229 & 59.0 & $\begin{array}{l}\text { TAGTTGGTGGAGCGATT } \\
\text { TGTCTG }\end{array}$ & $\begin{array}{l}\text { CTAAGCGGCATAGTCCCTC } \\
\text { TAAG }\end{array}$ & Tong et al. (2009) \\
\hline
\end{tabular}

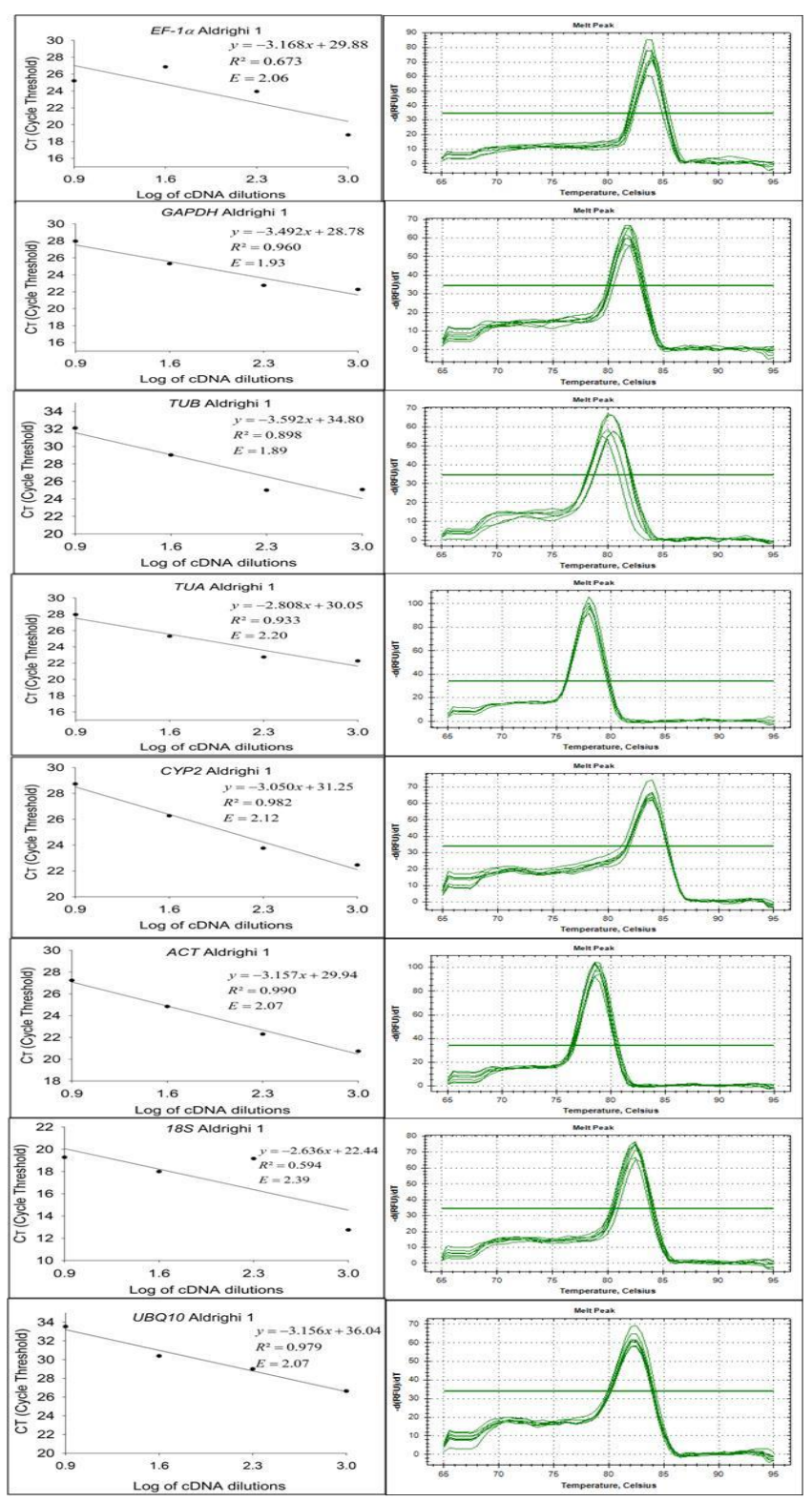

Fig 1. Efficiency and specificity of eight reference genes in leaf samples of peach tree cultivar Chimarrita grafted onto 'Aldrighi 1' rootstock, subjected to water deficit for different periods. 
Table 2. Average $(\bar{X})$, coefficient of variation (CV\%) and standard deviation (SD) of eight reference genes in leaf samples of peach tree cultivar Chimarrita grafted onto 'Aldrighi 1' and 'Tsukuba 2' rootstocks, subjected to water deficit.

\begin{tabular}{lcccccccc}
\hline ALDRIGHI 1 & TUA & CYP2 & UBQ10 & TUB & 18 SrRNA & GADPH & $E f-1 \alpha$ & $A C T$ \\
\hline Average $\bar{X}$ & 3.69 & 3.26 & 3.84 & 2.98 & 3.11 & 3.98 & 5.91 & 5.17 \\
CV\% & 11.01 & 11.22 & 18.30 & 39.90 & 25.12 & 24.04 & 25.10 & 45.71 \\
SD & 0.40 & 0.36 & 0.70 & 1.18 & 0.78 & 0.95 & 1.48 & 2.36 \\
\hline TSUKUBA 2 & & & & & & & & \\
Average $\bar{X}$ & 2.45 & 2.10 & 1.40 & 1.56 & 1.47 & 1.96 & 2.31 & 1.97 \\
CV\% & 8.42 & 22.40 & 47.01 & 28.91 & 32.96 & 38.53 & 17.66 & 63.44 \\
SD & 0.20 & 0.47 & 0.66 & 0.45 & 0.48 & 0.75 & 0.40 & 1.25 \\
\hline
\end{tabular}

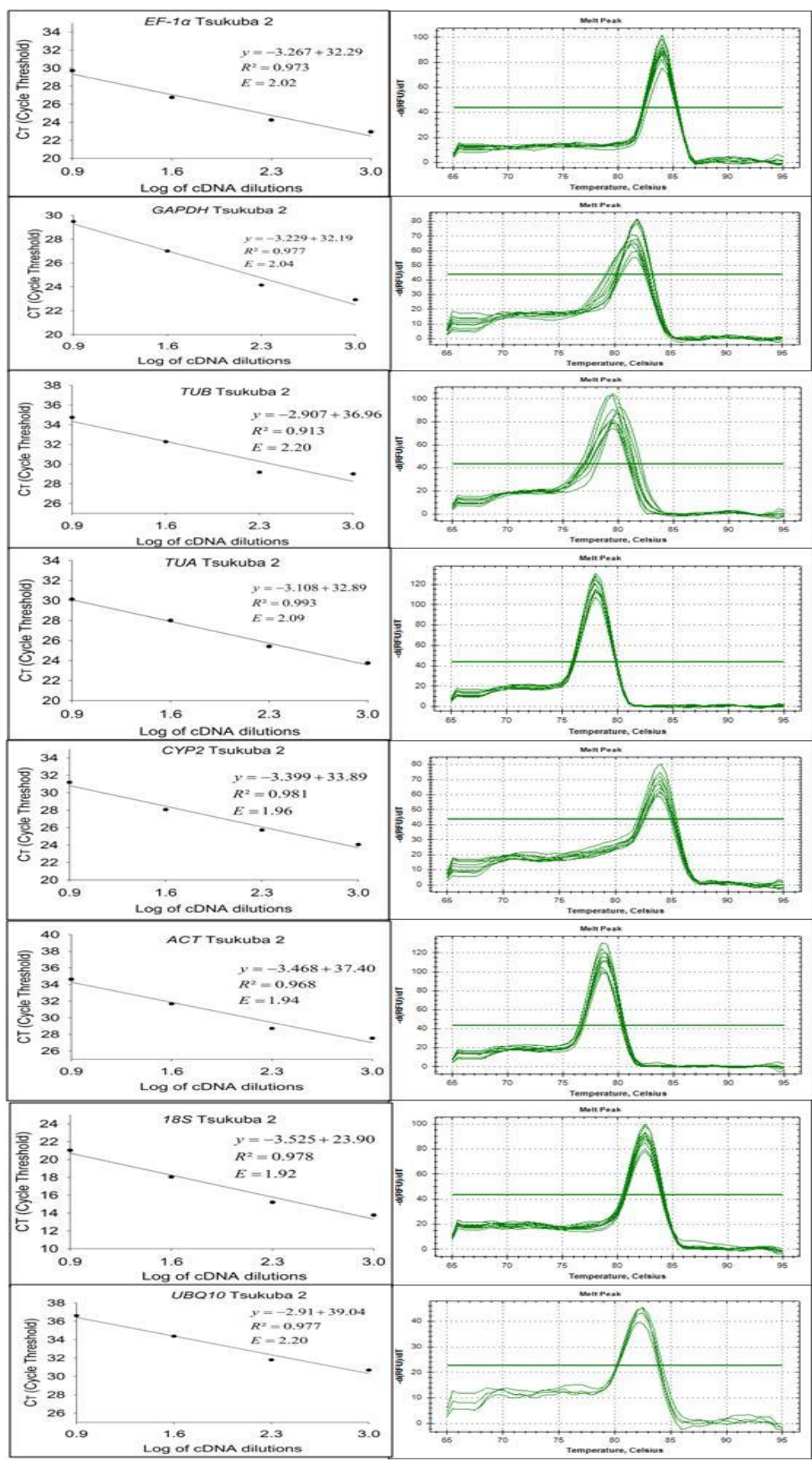

Fig 2. Efficiency and specificity of eight reference genes in leaf samples of peach tree cultivar Chimarrita grafted onto 'Tsukuba 2' rootstock, subjected to water deficit for different periods. 

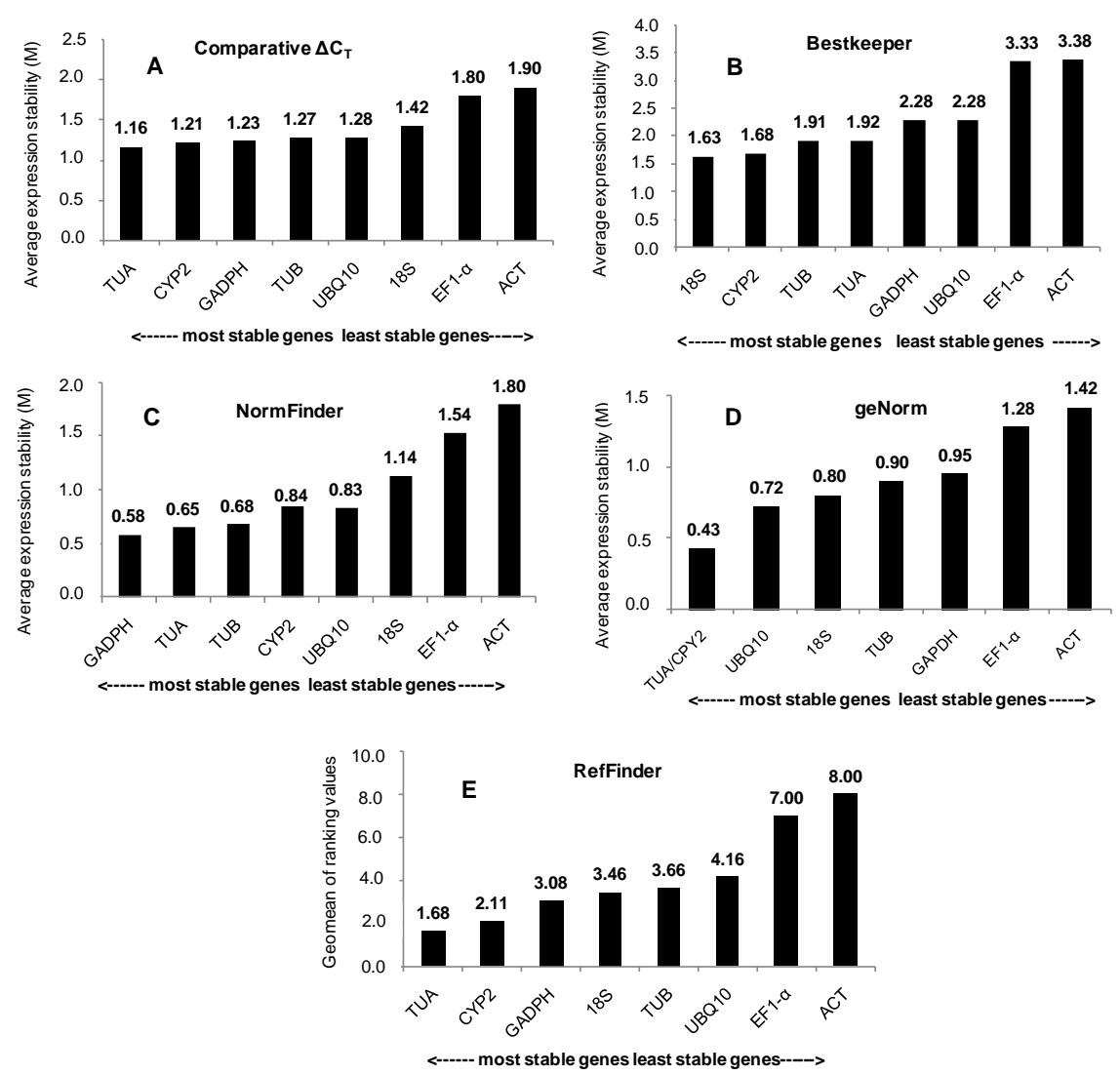

Fig 3. Average stability of expression of eight reference genes according to the algorithms (A) $\Delta \mathrm{C}_{\mathrm{T}}$ comparative method, (B) Bestkeeper, (C) NormFinder, (D) geNorm, and (E) RefFinder-Ranking in leaf samples of peach trees cultivar scion 'Chimarrita' grafted onto 'Aldrighi 1' rootstock, subjected to water deficit.
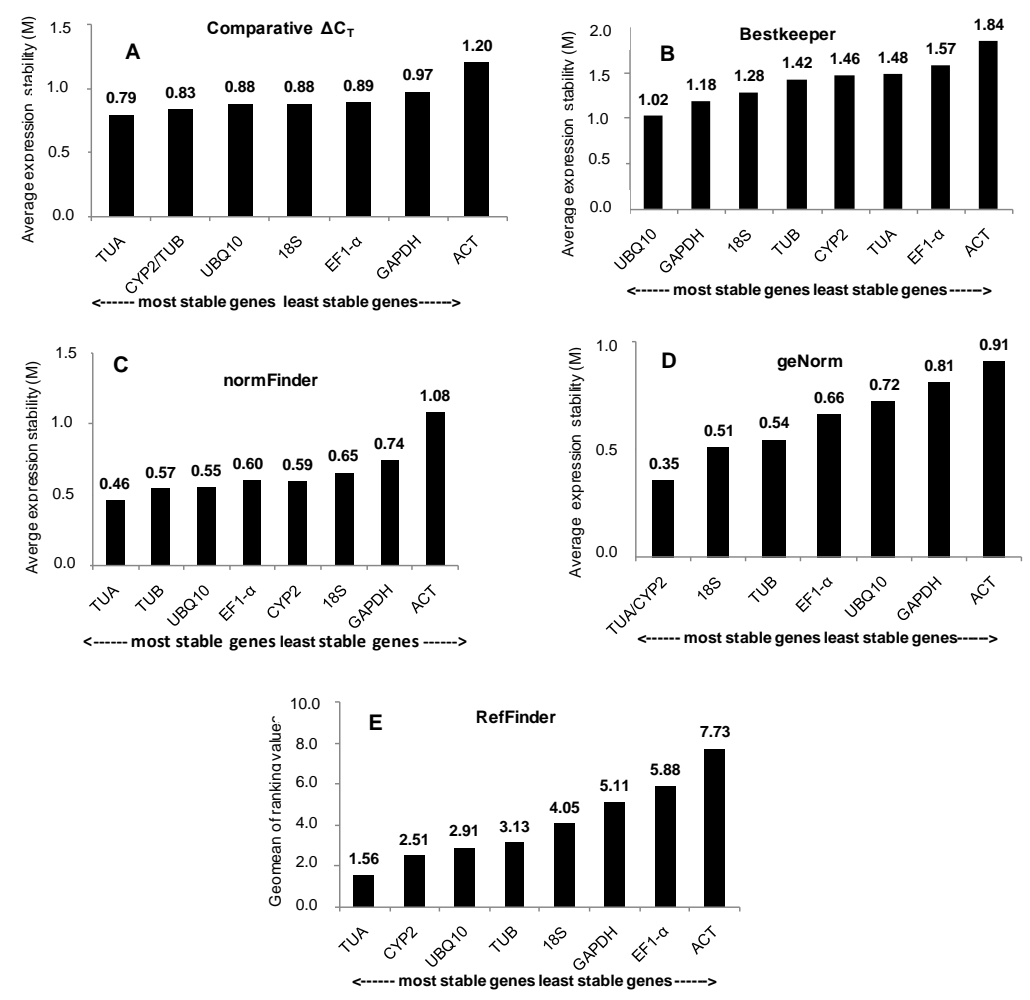

Fig 4. Average stability of expression of eight reference genes according to the algorithms (A) $\Delta \mathrm{C}_{\mathrm{T}}$ comparative method, (B) Bestkeeper, (C) NormFinder, (D) geNorm, and (E) RefFinder-Ranking in leaf samples of peach trees cultivar scion 'Chimarrita' grafted onto 'Tsukuba 2' rootstock, subjected to water deficit. 
whereas $A C T(\mathrm{M}=1.42$ and $\mathrm{M}=0.91)$ was the most variable/unstable (Fig 3D and Fig 4D, respectively).

Besides integrating the four methods abovementioned, the software RefFinder (Fig 3E and Fig 4E) uses $\mathrm{C}_{\mathrm{T}}$ values to assign a given value for a single gene and calculates the geometric mean of its values for the final ranking, based on the ratings of each one of the four programs (Chen et al., 2011).

Although RefFinder does not indicate a cutoff value to rank a reference gene as stable or unstable, this software provides a ranking of candidate genes according to their stability. In this case, candidate genes with the lowest ranking were considered to be expressed as stable under the experimental conditions investigated and, therefore, can be selected as ideal reference genes. As it is observed in Fig 3E, the overall ranking of stability in the graft combination 'Chimarrita/Aldrighi 1' was determined as: TUA > CYP2 > $G A P D H>18 S r R N A>T U B>U B Q 10>E f-1 \alpha>A C T$, which was a little different compared to the stability of the graft combination 'Chimarrita/Tsukuba 2' whose ranking was: $T U A>C Y P 2>U B Q 10>T U B>18 S r R N A>G A P D H>E f$ $1 \alpha>A C T$ (Fig 4E). Therefore, the RefFinder was used as a confirmation tool to select the most suitable reference genes, since a few differences in the level of stability of expression were observed among the approaches studied.

\section{Discussion}

The analysis of gene expression to better understand certain processes that control biological traits has increased considerably in the past decades and, currently, RT-qPCR is the most common technique used to analyze the expression of transcripts (Mallona et al., 2010). This technique is accurate and reliable, moreover, it is used to validate data obtained by other methods. Undoubtedly, its advantages are the high sensitivity, the real-time detection of the progress of the reaction, velocity of the analysis and accurate measurement of the material examined in the sample (Gachon et al., 2004). Studies of gene expression through RT-qPCR require the knowledge about the reference genes stably expressed for the normalization data of target genes (Bustin et al., 2009; Derveaux et al., 2010). For this purpose, several genes evolved in basic cellular processes are usually known as constitutive and hence extensively used as normalizing genes in RT-qPCR analyses. However, these genes may vary significantly in their expression, therefore being unsuitable for use as internal control of certain experimental conditions because might result in the misinterpretation data (Tong et al., 2009; Hu et al., 2014; Galli et al., 2015).

Glyceraldehyde-3-phosphate dehydrogenase is one of the reference genes commonly used to normalize RT-qPCR data. The use of GAPDH in many studies has provided good results (Cruz et al., 2009), otherwise, in other studies it is not recommended due to the variability of expression posed by different experimental conditions (Tong et al., 2009; Hu et al., 2014; Huang et al., 2014; Galli et al., 2015; Ye et al., 2015). In this paper, GAPDH has proven to be quite unstable in most of the algorithms used and also had a high CV\%, 24.04 for 'Chimarrita/Aldrighi 1' and 38.53 for 'Chimarrita/Tsukuba 2' graft combination. The possible explanation for this high variability may be due to the fact that $G A P D H$ plays a role as a compound of the glycolytic pathway by converting glyceraldehyde-3-phosphate to 1,3bisphosphoglycerate along with the reduction of $\mathrm{NAD}^{+}$to $\mathrm{NADH}_{2}$, besides taking part in other cell processes, so that, the profile of expression of this gene may have been influenced under the experimental conditions of this study.
Actin is an intracellular protein quite abundant in eukaryotic cells and their highest concentration is in the cell cortex. Genes encoding actin are commonly used as normalizing in many studies of expression (Jain et al., 2006). Among the eight reference genes tested in the present study, $A C T$ was considered to be the most unstable in the four algorithms analyzed (Fig 3 A-E and Fig 4 A-E) also having the highest CV\% and SD (Table 2). Tong et al. (2009), have also found an increased instability of this gene in peach plants. $A C T$ has also demonstrated instability in other studies, such as those carried out by Galli et al. (2015), in Fragaria x ananassa Duch subjected to water deficit and by Jain et al. (2006) in Oryza sativa under different experimental conditions. In contrast, in Prunus sibirica L. seeds, ACT was one the most stable genes according to the algorithms geNorm and NormFinder (Niu et al., 2014).

In leaves and roots of Dactylis glomerata L., the genes ACT and $C P Y 2$ had an increased stability in plants subjected to water deficit (Huang et al., 2014). These same genes have also been the most stable based on the algorithms geNorm and NormFinder in flowers and fruits of cherry tree (Ye et al., 2015). In the present study, the gene CYP2 has also shown high stability as the second most stable gene in the ranking (RefFinder) (Fig 3E and Fig 4E). Cyclophilins are a family of proteins found in very diverse organisms from prokaryotes to humans. Such molecules are related to the function of modulation of membrane permeability in mitochondria and also influence the conformation of proteins in cells (Lewin, 1997), thus, they are often used as reference genes in many studies.

Ubiquitin is an essential protein in the regulation of biological processes, directly involved in signaling complexes of other proteins (Sun et al., 1997), besides taking part in the structure and transcription of chromatin, DNA repairing, regulation of endocytosis and transport of proteins (Hernandez-Garcia et al., 2009). When investigating the expression of eleven reference genes in different samples of Prunus persica, Tong et al. (2009) found that UBQ10 had a stable expression as normalizing in this species. In the present study, such behavior has not been proven because $U B Q 10$ has not been properly stable in all algorithms analyzed (Fig 3 and Fig 4), contrasting with the results found by Galli et al. (2015), where the $U B Q 11$ gene was the second most stable gene according to the general ranking (RefFinder) in strawberry plants under water deficit.

Ribosomes in eukaryotes have four different rRNA molecules: $5 \mathrm{~S}, 5.8 \mathrm{~S}, 18 \mathrm{~S}$, and $28 \mathrm{~S}$. These rRNA molecules along with ribosomal proteins make up two ribosomal subunits $40 \mathrm{~S}$ and $60 \mathrm{~S}$. The rRNA molecules play different roles in the synthesis of proteins. Ribosomal subunits, such as $18 \mathrm{~S}$, are widely used as reference genes. However, the use of the gene $18 \mathrm{~S}$ as a reference is not always suitable because it does not have the poly-A tail that hinders the synthesis of cDNA with oligo-dT primers. Besides, the ribosomal gene $18 S$ is not always a completely representative of mRNA cell population. In the present study, this gene had varied stability and it was the most stable only in the algorithm BestKeeper for the graft combination 'Chimarrita/Aldrighi 1' (Fig 3B). Galli et al. (2015) did not recommend it as a possible reference gene for strawberry plants under osmotic stress and water deficit. In peach trees, under different experimental conditions and tissues, Tong et al. (2009) have also found an increased variability for this gene.

The elongation factor $1 \alpha$ in eukaryotes is a highly conserved member of the GTPases family, which includes protein factors involved in the initiation, elongation, and end of translation, besides being involved in other cellular 
functions, such as interaction with protein of the cytoskeletal, calmodulin as well as with the ubiquitin-dependent proteolytic system (Keeling et al., 2004). As it was found by Niu et al. (2014) in Prunus sibirica L., and by $\mathrm{Hu}$ et al. (2014) in Fortunella crassifolia Swingle under different abiotic stresses, the gene $E f-1 \alpha$ had shown variability in the stability expression corroborating our results as it can be seen on the ranking of stability (RefFinder) (Fig 3E and Fig 4E).

Tubulins comprise a small family of globular proteins. The most common members of this family are $\alpha$-tubulin and $\beta$ tubulin, which are the proteins that make up microtubules, playing a crucial role in several basic processes such as cell division, intracellular transport, cell motility, morphogenesis, and maintenance of cell shape (Ludwig et al., 1987; Whittaker and Triplett, 1999). In this paper, we analyzed both tubulin genes ( $\alpha$ and $\beta$ ), and the gene $T U B$ was more instable than the gene TUA in our experimental conditions. TUA was the most stable gene in comparison to all the other genes, which is demonstrated in all algorithms analyzed in addition to the lowest SD (0.20) and CV\% (8.42) values in the graft combination 'Chimarrita/Tsukuba 2' (Table 2). Moreover, Ye et al. (2015) reported a high stability of this gene in vegetative tissues and organs of cherry trees. In contrast, Tong et al. (2009) reported no stability of this gene in different genotypes, tissues, and developmental stages of fruits in Prunus persica. Hu et al. (2014) have also reported no stability of the gene TUA in Fortunella crassifolia Swingle under water deficit.

The results obtained in this study lead us to suggest that constitutive genes may be regulated differently in different plant species, confirming that in general there is no universal reference gene applicable to all experimental conditions and the reference transcripts commonly used may not always exhibit similar constitutive expression. The contradiction of these, as well as other findings, confirms the need of an adequate selection of the constitutive gene as control for analyses of expression of transcripts through RT-qPCR.

The major characteristic of a reference gene is the stability of expression that should not be affected by the tissue type, development period or physiological conditions of the plant. The use of unsuitable reference genes leads to differences in the profile of relative expression. Then, our results showed the importance of previously validated reference genes for the experimental conditions to be studied. Either erroneous or inconsistent interpretations may be taken forward if a previous validation is not conducted for the desired experimental conditions.

\section{Materials and Methods}

\section{Plant material and water deficit conditions}

Peach trees cultivar Chimarrita, with 2-year-old, grafted onto two rootstocks of Prunus persica ('Aldrighi 1' and 'Tsukuba 2 ') were growth into pots with 25-liter capacity filled with soil substrate classified as dystrophic yellow-red argisol (Streck et al., 2008). The plants were kept in a greenhouse, and irrigated daily up to field soil capacity until the beginning of the trail on day zero (control), when the irrigation was suspended during 9-day period to induce the stress by water deficit. The 9-d period of plant evaluation was based on morphological and physiological characteristic of the leaves, such as: decrease in stomatal conductance, epinasty, and early leaf abscission, which was also previously referenced by Martinazzo et al. $(2011 ; 2013)$ in plants of Prunus spp. under water stress treatments. In the present study, three plants of each graft combination 'Chimarrita'/rootstock were maintained under regular irrigation supply just to track the physiological characteristics of the leaves in relation to the plants under water deficit.

The trial was conducted in a completely randomized design with four treatments that correspond the evaluations period: zero (control), $4^{\text {th }}, 7^{\text {th }}$, and $9^{\text {th }}$ stress day of water deficit. For each treatment three biological replicates was used. In each period of evaluation leaves were sampled from cultivar Chimarrita, immediately frozen in liquid nitrogen and subsequently stored in an ultrafreezer at $-80{ }^{\circ} \mathrm{C}$ up to RNA extraction. Leaf samples of each graft combination cultivar Chimarrita onto the two rootstocks were analyzed separately.

\section{Total RNA isolation and cDNA synthesis}

The total RNA was extracted from $100 \mathrm{mg}$ of leaf tissue that had been grounded in liquid nitrogen and poured into $2 \mathrm{~mL}$ polypropylene tubes, added with $900 \mu \mathrm{L}$ CTAB buffer $65^{\circ} \mathrm{C}$ pre-heated. Samples were homogenized in vortex, incubated in a water bath at $65{ }^{\circ} \mathrm{C}$ for 30 minutes and cooled. Then, the extraction was carried out with successive centrifugation steps, following the protocol proposed by Chang et al. (1993), with small modifications.

The RNA pellet was dissolved with $30 \mu \mathrm{L} 0.01 \%$ DEPC autoclaved water, homogenized in vortex and stored in ultrafreezer. The concentration and purity of RNA were measured in NanoDrop ND-1000 (260/280nm) whereas the quality and integrity were verified by electrophoresis in $1.0 \%$ agarose gel. Single-stranded cDNAs were synthesized by reverse transcription from $1.5 \mu \mathrm{g}$ total RNA by using the kit GoScript $^{\mathrm{TM}}$ Reverse Transcription System (Promega) in a reaction with a final volume of $20 \mu \mathrm{L}$ with oligo-dT primers according to the manufacturer's instructions.

\section{Selection of candidate reference gene under water deficit}

We selected eight reference genes to be tested in this study. They are reported in literature as internal control in RT-qPCR analyses and, supposedly, have no significant variation in different experimental conditions. The genes selected were: $A C T, C Y P 2$, Efl- $\alpha$, GAPDH, TUA, TUB, UBQ10 and 18SrRNA (Table 1).

\section{Reverse transcription quantitative PCR}

The total volume of each RT-qPCR reaction was $12 \mu \mathrm{L}, 6.25$ $\mu \mathrm{L}$ SYBR Green fluorophore (Invitrogen $\left.{ }^{\circledR}\right), 0.25 \mu \mathrm{L}(10 \mathrm{mM})$ of each primer (forward and reverse), $1 \mu \mathrm{L}$ cDNA (dilution $1: 5$, previously determined), $4.15 \mu \mathrm{L}$ ultrapure water, and 0.1 $\mu \mathrm{L}$ ROX. The amplification was standardized in a CFX-96 Real Time Thermal Cycler (Bio-Rad) equipment, by using the following amplification conditions: $95^{\circ} \mathrm{C}$ for 10 minutes, 40 cycles of $95{ }^{\circ} \mathrm{C}$ for 15 seconds, $60{ }^{\circ} \mathrm{C}$ for 1 minute with the insertion of the melting curve from $65^{\circ} \mathrm{C}$ to $95^{\circ} \mathrm{C}$, increasing $5{ }^{\circ} \mathrm{C}$ at every fluorescence measurement. Three biological replicates were used.

\section{Specificity and efficiency of standard curve}

The specificity of primers was assessed through the dissociation curve (melting curve) and we maintained only primers with specific amplicons that show a single peak of dissociation of strands of PCR products.

The efficiency of PCR $(E)$ was obtained from four serial dilutions of cDNA $(1: 1,1: 5,1: 25$, and $1: 125)$ in order to generate the standard curve of each pair of primer tested. The value of $E$ was estimated by the equation $E=10^{(1 / \text { slope })}$ 
(Rasmussen, 2001), where slope is the curvature of the line obtained from the regression between $\mathrm{C}_{\mathrm{T}}$ values (Cycle Threshold) of transcripts and the values from the algorithm of different cDNA dilutions (standard curve of efficiency), considered as acceptable efficiency values ranging from 1.8 to 2.2 , which corresponds to a reaction efficiency between 90 $-110 \%$ (Fig 1, and Fig 2).

\section{Data analysis}

In order to classify and determine the performance of each reference gene, the means of $\mathrm{C}_{\mathrm{T}}$ values (Le et al., 2012; Niu et al., 2014) were used for each sample analyzed, obtained from each RT-qPCR reaction cycle. Data was subjected to the analysis of variance through the Statistical Analysis System - WinStat - Version 2.0 (Machado and Conceição, 2003), and the normalizing genes with the lowest standard deviation and coefficient of variation values were considered to be stable.

In parallel with statistical analyses, the stability of normalizing genes for both combinations 'Chimarrita'/rootstocks was assessed with the tool RefFinder, available on the website http://fulxie.Ofees.us/?type= reference\&ckattempt $=1$, which integrates the computational algorithms geNorm, NormFinder, BestKeeper, and $\Delta \mathrm{C}_{\mathrm{T}}$ comparative method to compare and rank the stability of candidate genes to normalizing. $\mathrm{C}_{\mathrm{T}}$ values of each gene were used by these algorithms to determine the stability of relative expression. Among these four algorithms, geNorm and NormFinder use relative expression values calculated from $\mathrm{C}_{\mathrm{T}}$ values whereas BestKeeper and $\Delta \mathrm{C}_{\mathrm{T}}$ comparative method use directly $C_{T}$ values inserted onto RefFinder (Chao et al., 2012). In addition to the isolated analysis of each algorithm, an overall ranking of the best normalizing for the experimental condition investigated was obtained by combining the results of four algorithms. The detailed calculation of each one of the methods is described in Chen et al. (2011)

\section{Conclusion}

The analysis of expression stability of eight candidate genes to normalizing for RT-qPCR studies suggests the constitutive genes TUA and CYP2 as the most suitable for studies in peach leaves cultivar Chimarrita grafted onto 'Aldrighi 1' and 'Tsukuba 2' rootstocks under water deficit. The genes $E f$ $1 \alpha$ and ACT are the least suited for the experimental conditions tested.

\section{Acknowledgements}

The authors are grateful to the Coordenação de Aperfeiçoamento de Pessoal de Nível Superior (CAPES) and Conselho Nacional de desenvolvimento Científico e Tecnológico $(\mathrm{CNPq})$ for their financial support.

\section{References}

Almada R, Arismendi MJ, Pimentel P, Rojas P, Hinrichsen P, Pinto M, Sagredo B (2013) Class 1 non-symbiotic and class 3 truncated hemoglobin-like genes are differentially expressed in stone fruit rootstocks (Prunus L.) with different degrees of tolerance to root hypoxia. Tree Gen Genom. 9:1051-1063.

Amil-Ruiz F, Garrido-Gala J, Blanco-Portales R, Folta KM, Muñoz-Blanco J, Caballero J L (2013) Identification and validation of reference genes for transcript normalization in strawberry (Fragaria $\times$ ananassa) defense responses. PLoS One. 8:1-18.

Andersen CL, Jensen JL, Orntoft TF (2004) Normalization of real-time quantitative reverse transcription-PCR data: a model-based variance estimation approach to identify genes suited for normalization, applied to bladder and colon cancer data sets. Cancer Res. 64:5245-5250.

Arismendi MJ, Almada A, Pimentel P, Bastias A, Salvatierra A, Rojas P, Hinrichsen P, Pinto M, Di Genova A, Travisany D, Maass A, Sagredo B (2015) Transcriptome sequencing of Prunus sp. rootstocks roots to identify candidate genes involved in the response to root hypoxia. Tree Gen Genom. 11:1-16.

Bustin S (2002) Quantification of mRNA using real-time reverse transcription PCR (RT-PCR): trends and problems. J Mol Endocrinol. 29:23-39.

Bustin SA, Benes V, Garson JA, Hellemans J, Huggett J, Kubista M, Mueller R, Nolan T, Pfaff MW, Shipley GL,Vandesompele J, Wittwer, CT (2009) The MIQE guidelines: minimum information for publication of quantitative real-time PCR experiments. Clin Chem. 55:611-622.

Chang S, Puryear J, Cairney J (1993) A simple and efficient method for isolating RNA from pine. Plant Mol Biol Rep. 11:113-116.

Chao WS, Dogramaci M, Foley ME, Horvath DP, Anderson JV (2012) Selection and validation of endogenous reference genes for qRT-PCR analysis in Leafy Spurge (Euphorbia esula). PLoS ONE. 7:1-10.

Chaves MM, Flexas J, Pinheiro C (2009) Photosynthesis under drought and salt stress: regulation mechanisms from whole plant to cell. Ann Bot.103:551-560.

Chen L, Zhong HY, Kuang JF, Li JG, Lu WJ, Chen JY (2011) Validation of reference genes for RT-qPCR studies of gene expression in banana fruit under different experimental conditions. Plant. 234:377-390.

Cruz F, Kalaoun SP, Nobile C, Almeida J, Barros L, Romano E, Grossi-De-Sá, MF, Vaslin M, Ferreira AM (2009) Evaluation of coffee reference genes for relative expression studies by quantitative real-time RT-PCR. Mol Breed. 23:607-616.

Derveaux S,Vandesompele J, Hellemens J (2010) How to do successful gene expression analysis using real-time PCR. Methods. 50:227-230.

Dichio B, Xiloyannis C, Sofo A, Montanaro G (2006) Effects of postharvest regulated deficit irrigation on carbohydrate and nitrogen partitioning, yield quality and vegetative growth of peach trees. Plant Soil. 290:127-137.

Expósito-Rodríguez M, Borges AA, Borges-Pérez A, Pérez JA (2008) Selection of internal control genes for quantitative real-time RT-PCR studies during tomato development process. BMC Plant Biol. 131:1-12.

Gachon C, Mingan A, Charrier B (2004) Real time PCR: what relevance to plant studies? J Exp Bot. 55:1445-1454.

Galli V, Borowski JM, Perin EC, Messias RS, Labonde J, Pereira IS, Anjos SDA, Rombaldi CV (2015) Validation of reference genes for accurate normalization of gene expression for real time quantitative PCR in strawberry fruits using different cultivars and osmotic stresses. Gene. 554:205-214.

Hernandez-Garcia CM, Martinelli AP, Bouchard RA, Finer JJ (2009) A soybean (Glycine max) polyubiquitin promoter gives strong constitutive expression in transgenic soybean. Plant Cell Rep. 28:837-849. 
Hu Y, Chen H, Luo C, Dong L, Zhang S, He X, Huang G (2014) Selection of reference genes for real-time quantitative PCR studies of kumquat in various tissues and under abiotic stress. Sci Hort. 174:207-216.

Huang L, Yan H, Jiang X, Zhang Y, Zhang X, Yang J, Zeng B, Yin G, Lee S, Yanhong Y, Xiao M, Peng Y (2014) Reference gene selection for quantitative real-time reversetranscriptase PCR in orchardgrass subjected to various abiotic stresses. Gene. 553:158-165.

Jain M, Nijhawan A, Tyagi AK, Khurana JP (2006) Validation of housekeeping genes as internal control for studying gene expression in rice by quantitative real-time PCR. Biochem Biop Res Comm. 34:646-651.

Jiménez S, Dridi J, Gutiérrez D, Moret D, Irigoyen JJ, Moreno MA, Gogorcena Y (2013) Physiological, biochemical and molecular responses in four Prunus rootstocks submitted to drought stress. Tree Physiol. 33:1061-1075.

Keeling PJ, Inagaki Y (2004) A classic of eukaryotic GTPase with a punctuate distribution suggesting multiple functional replacements of translation elongation factor 1 alpha. Proc Nat Acad Sci. 101:15380-15385.

Le DT, Aldrich DL, Valliyodan B, Watanabe Y, HA CV, Nishiyama R, Guttikonda SK, Quach T, GutierrezGonzalez JJ, Tran LSP, Nguyen HT (2012) Evaluation of Candidate Reference Genes for Normalization of Quantitative RT-PCR in Soybean Tissues under Various Abiotic Stress Conditions. PLoS ONE. 7:1-10.

Lewin B. (1987) “GENES VI”. New York: Oxford University Press, 1997, 1260p.

Ludwig SR, Oppenheimer DG, Silflow CD, Snustad DP (1987) Characterization of the a-tubulin gene family of Arabidopsis thaliana. Proc Nat Acad Sci. 84:5833-5837.

Luo X, Shi T, Sun H, Song J, Ni Z, Gao Z (2014) Selection of suitable inner reference genes for normalization of microRNA expression response to abiotic stresses by RTqPCR in leaves, flowers and young stems of peach. Sci Hort. 165:281-287.

Machado AA, Conceição AR. Sistema de análise estatística para Windows. WinStat. Versão 2.0. UFPel, 2003.

Mallona I, Lischewski S, Weiss J, Hause B, Egea-Cortines M (2010) Validation of reference genes for quantitative realtime PCR during leaf and flower development in Petunia hybrida. BMC Plant Biol. 10:4.

Martinazzo EG, Perboni AT, Farias ME, Bianchi VJ, Bacarin MA (2011) Photosynthetic activity in the rootstock of hybrid peach trees submitted to water restriction and flooding. Braz Soc of Plant Physiol. 23:231-236.

Martinazzo EG, Perboni AT, Oliveira PV, Bianchi VJ, Bacarin MA (2013) Atividade fotossintética em plantas de ameixeira submetidas ao déficit hídrico e ao alagamento. Cienc Rural. 43:35-41.

Mercier V, Bussi C, Lescourret F, Genard M (2009) Effects of different irrigation regimes applied during the final stage of rapid growth on an early maturing peach cultivar. Irrig Sci. 27:297-306.

Moraes GP, Benitez LC, Do Amaral, MM, Vighi IL, Auler PA, Maia LC, Bianchi VJ, Braga EJB (2015) Evaluation of reference genes for RT-qPCR studies in the leaves of rice seedlings under salt stress. Gen Mol Res. 14:2384-2398.
Nakashima K, Yamaguchi-Shinozaki K, Shinozaki K (2014) The transcriptional regulatory network in the drought response and its crosstalk in abiotic stress responses including drought, cold, and heat. Front Plant Sci. 5:1-7.

Niu J, Zhu B, Cai J, Li P, Wang L, Dai H, Qiu L, Yu H, Denglong A, Zhao H, Zhang Z, Lin S (2014) Selection of Reference Genes for Gene Expression Studies in Siberian Apricot (Prunus sibirica L.) Germplasm Using Quantitative Real-Time PCR. PLoS ONE. 9:1-10.

Pfaffl MW (2001) A new mathematical model for relative quantification in real time RTPCR. Nucl Acids Res. 29:2002-2007.

Pfaffl MW, Tichopad A, Prgomet C, Neuvians TP (2004) Determination of stable housekeeping genes, differentially regulated target genes and sample integrity: BestKeeperExcel-based tool using pair-wise correlations. Biotec Lett. 6:509-515.

Rasmussen RP (2001) Quantification on the Light Cycler. In: Meuer S, Wittwer CT and Nakagawara K (eds) Rapid Cycle Real-time PCR, Methods and Applications. 1st edition. Springer Press, Heidelberg. 21-34.

Silver N, Best S, Jiang J, Thein SL (2006) Selection of housekeeping genes for gene expression studies in human reticulocytes using real-time PCR. BMC Mol Biol. 7:33-42.

Streck EV, Kämpf N, Dalmolin RSD, Klamt E, Nascimento PC, Schneider P, Giasson E, Pinto LFS. Solos do Rio Grande do Sul. 2.ed. Porto Alegre: UFRGS, 2008. 222p.

Sun CW, Griffen S, Callis, J (1997) A model for the evolution of polyubiquitin genes from the study of Arabidopsis thaliana ecotypes. Plant Mol Biol. 3:745-758.

Timm LC. Manejo da Irrigação na Cultura do Pessegueiro: manual técnico. Pelotas: Ed. da Universidade Federal de Pelotas, 2007, 110p.

Tong Z, Gao Z, Wang F, Zhou J, Zhang Z (2009) Selection of reliable reference genes for gene expression studies in peach using realtime PCR. BMC Mol Biol. 71:1-13.

Vandesompele J, De Preter K, Pattyn F, Poppe B,Van Roy N, De Paepe A, Speleman F (2002) Accurate normalization of real-time quantitative RT-PCR data by geometric averaging of multiple internal control genes. Genome Biol. 3:1-12.

Wang D, Gartung J (2010) Infrared canopy temperature of early-ripening peach trees under postharvest deficit irrigation. Agric Wat Manag. 97:1787-1794.

Whittaker DJ,Triplett BA (1999) Gene-Specific Changes in a-Tubulin Transcript Accumulation in Developing Cotton Fibers. Plant Physiol. 121:181-188.

Xu Y, Zhang L, Xie H, Zhang YQ, Oliveira MM, Rong-Cai MA (2008) Expression analysis and genetic mapping of three SEPALLATA-like genes from peach (Prunus persica (L.) Batsch). Tree Genet Genomes. 4:693-703.

Ye X, Zhang F, Tao Y, Song S, Fang J (2015) Reference gene selection for quantitative real-time PCR normalization in different cherry genotypes, developmental stages and organs. Sci Hort. 18:182-18. 